\title{
Analisis Keanekaragaman Jenis Tumbuhan Pada Dua Sub Komunitas Di Hutan Lindung Nua Nea Pulau Seram Maluku Tengah
}

\author{
Wahyudi $^{1}$, Jumrin Said ${ }^{2}$, Rismawati ${ }^{3}$ \\ ${ }^{1}$ Program Studi Kehutanan Universitas Sulawesi Barat dan Pusat Penelitian dan Pengembangan Lingkungan Hidup \\ Universitas Hasanuddin \\ ${ }^{2}$ PEH Balai Taman Nasional Manusela \\ ${ }^{3}$ PEH Balai Perbenihan Tanaman Hutan Wilayah II \\ aurelia.nilani@gmail.com
}

\begin{abstract}
Abstrak
Hutan Lindung Nua Nea secara geografis terletak bersebelahan dengan Taman Nasional Manusela dan keberadaannya memiliki arti penting yang dapat dipandang sebagai kawasan penyangga dari taman nasional tersebut. Hutan ini memiliki nilai keanekaragaman hayati yang tinggi dan telah lama dimanfaatkan oleh masyarakat sekitar untuk berbagai keperluan. Penelitian ini bertujuan mempelajari keanekaragaman jenis pohon yang tumbuh pada kompleks Hutan Lindung Nua Nea. Metode penelitian dilakukan dengan pencacahan dan identifikasi jenis tanaman tingkat pohon yang ada dalam plot contoh. Hasil analisis menunjukkan bahwa total kekayaan jenis tumbuhan yang tercatat pada plot pengamatan terdiri atas 60 jenis, 50 marga dan 33 suku tumbuhan tingkat pohon dengan Suku Sapotaceae dan Euphorbiaceae yang mendominasi distribusi jenis pohon. Untuk komunitas I pada Hutan Lindung Nua Nea ini, jenis pohon Syzygium sp.1 merupakan jenis pohon dominan dengan nilai penting yang tertinggi, yaitu sebesar 68,979 \%. Untuk komunitas II, jenis pohon yang memiliki nilai penting tertinggi adalah Syzygium sp.2, yaitu sebesar 23,76 \%. Namun demikian, pada komunitas II ini tampak tidak ada jenis yang terlalu mendominasi dalam hal jumlah jenis maupun jumlah individu.
\end{abstract}

Keywords: Keanekaragaman, Hutan, Manusela, Nuanea, Sub-komunitas

\section{Pendahuluan}

Hutan merupakan sumber daya alam yang memiliki peranan yang sangat penting dalam sistem penyangga kehidupan. Selain sebagai habitat bagi beragam organisme yang saling berinteraksi dengan lingkungannya, hutan juga memiliki peran secara fisik dalam menjaga stabilitas lingkungan, berperan penting dalam upaya konservasi tanah dan air serta menyediakan jasa-jasa lingkungan lainnya.

Demikian pula halnya dengan hutan alam Desa Nua Nea yangmemiliki peranan penting sebagai system penyangga kehidupan. Hutan ini merupakan hutan adat yang telah lama dimanfaatkan oleh masyarakat sekitar dan merupakan bagian penting bagi kehidupan mereka.Pemanfaatan hutan ini dahulunya baik sebagai tempat perlindungan dan mencari makan, maupun sampai saat ini tetap menjadi tempat berburu dan mencari pemenuhan kebutuhan keseharian.

Secara geografis hutan lindung ini terletak bersebelahan dengan Taman Nasional Manusela dan keberadaannya memiliki arti penting, yaitudapat dipandang sebagai kawasan penyangga dari taman nasional tersebut. Selain itu, hutan alam Desa Nua Nea ini merupakan bagian dari satu formasi hutan hujan dataran rendah dengan hutan TN Manusela dan memiliki nilai keanekaragaman hayati yang tinggi. Berbagai jenis organisme hidup pada hutan ini, termasuk pula Agrovital | Jurnal Ilmu Pertanian Universitas Al Asyariah tumbuhan, mulai dari tingkat pohon sampai beragam herba dapat dijumpai pada hutan ini.Pohon-pohon yang ada pada hutan ini merupakan komponen utama yang membentuk fisiognomi dan memberikan pengaruh besar terhadap lingkungan Hutan Nua Nea ini.

Keberadaan pohon-pohon ini juga secara langsung berperan dalam menjaga siklus hidrologi pada areal ini, yang mana sungai yang melintasi hutan ini dimanfaatkan sebagai pembangkit listrik oleh masyarakat sekitar dan dengan debit air sungai yang melimpah sepanjang tahun memiliki potensi yang besar untuk dikembangkan dalam skala yang lebih luas, yaitu dengan membangun pembangkit yang kapasitasnya lebih besar.

Tulisan ini bertujuan mempelajari tingkat keanekaragaman jenis pohon yang tumbuh pada kompleks Hutan Lindung Nua Nea yang terletak di tengah-tengah Pulau Seram berbatasan langsung dengan Taman Nasional Manusela.

\section{Metode Penelitian}

Penelitian ini dilaksanakan di hutan lindung Desa Nua Nea Kecamatan Amahai Propinsi Maluku Tengah. Pengambilan data dilaksanakan pada Bulan Mei 2012. Peralatan yang dipergunakan dalam penelitian ini, adalah kompas, tali, meteran rol, kaliper, pita diameter, galah 
pengukur tinggi tanaman $130 \mathrm{~cm}$, alat tulis, perlengkapan pembuatan herbarium dan buku identifikasi tumbuhan.

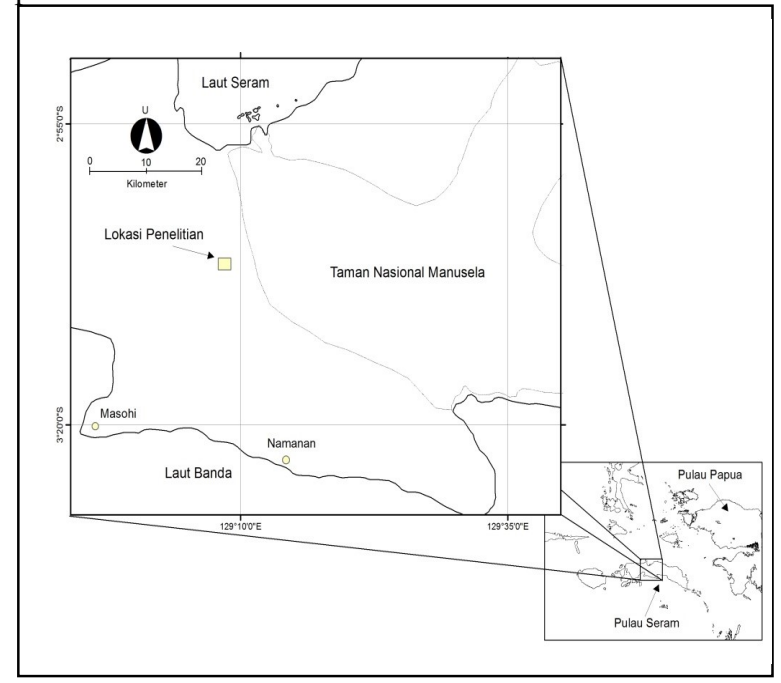

Gambar 1. Lokasi Penelitian

Dalam pengumpulan data, orientasi lapangan terlebih dahulu dilakukan untuk mempelajari komunitas hutan yang akan diamati. Peletakan plot sampel dilakukan secara purposive pada dua sub komunitas dengan menggunakan metode releve, yang mana sub komunitas tersebut dideliniasi berdasarkan komposisi jenis tumbuhan dominan yang menyusun (MuellerDombois and Ellenbereg, 1974; Brower, Zar and Von Ende, 1990; Soerianegara dan Indrawan, 2002). Pada dua sub komunitas tersebut masing masing diletakkansebanyak tiga relevé dengan ukuran20 x 20 meter dan didalamnya dibuat lagi subplot dengan ukuran 10 x 10 meter untuk memudahkan pencatatan. Semua tumbuhan berkayu (tidak termasuk liana) yang ditemukan pada setiap plot sampling diukur diameternya pada ketinggian $130 \mathrm{~cm}$ dari permukaan tanah. Jenis tumbuhan yang tidak diketahui namanya diambil specimen herbariumnya dan diidentifikasi lebih lanjut pada Laboratorium Konservasi Biologi Kehutanan Universitas Hasanuddin.

\section{Analisis Data}

Aspek kuantitatif dari dua sub komunitas ini disajikan dalam bentuk table komposisi yang memperlihatkan nilai luas bidang dasar atau basal area dan indeks nilai penting untuk setiap jenis yang tercatat (Mueller-Dombois and Ellenbereg, 1974; Brower, Zar and Von Ende, 1990; Soerianegara dan Indrawan, 2002). Untuk mengetahui nilai keanekaragaman jenis maka dihitung dengan rumus Shannon-Weiner (Magurran, 1987; Brower, Zar and Von Ende, 1990):

$$
H^{s}=-\sum P i \ln P i \quad P i=\frac{\mathrm{mi}}{\mathrm{N}}
$$

Dimana $H$ ' adalah Indeks keanekaragaman, $n i$ adalah jumlah individu jenis ke-I dan $N$ adalah jumlah individu total. Indeks keseragaman dihitung dengan rumus

Agrovital | Jurnal Ilmu Pertanian Universitas Al Asyariah sebagai berikut (Magurran, 1987; Brower, Zar and Von Ende, 1990):

$$
l^{s}=\frac{\mathbb{H}^{x}}{\operatorname{Rmax}} \quad H^{\prime} \max =\ln S
$$

Dimana $J$ ' adalah indeks keseragaman, $S$ adalah jumlah jenis dan $H^{\prime}$ adalah indeks keanekaragaman.

Indeks kesamaan komunitas Motyka dipergunakan untuk menentukan besarnya nilai kesamaan komposisi jenis penyusun dari dua sub-komunitas yang dipelajari (Mueller-Dombois and Ellenberg, 1974), yaitu:

Motyka's Index of Similarity (ISM)

$$
I S M=\frac{2 M w}{M a+M b} \times 100 \%
$$

Dimana:

$M w=\sum$ nilai kuantitatif terkecil (dalam hal ini nilai dominansi jenis)dari jenis yang terdapat pada dua komunitas,

$M a=\sum$ nilai kuantitatif semua jenis di komunitas 1,

$M b=\sum$ nilai kuantitatif semua jenis di komunitas 2

Nilai $I S$ berkisar antara $0-100$

\section{Hasil Dan Pembahasan}

Secara umum tipe vegetasi di lokasi penelitian yang bersebelahan dengan Taman Nasional Manusela adalah merupakan vegetasi hutan hujan (Souhuwat, 2006; Cosiaux, 2014). Vegetasi ini memiliki komposisi jenis penyusun yang relative beragam, yang mana terdiri dari berbagai jenis tumbuhan alami mulai dari herba dan paku-pakuan, liana sampai pohon besar yang tumbuh dengan rapat. Hutan inikemudian membentuk iklim mikro dengan tajuk-tajuk pohon yang bersentuhan satu sama lainyang menyebabkan kondisi udara dibawah tajuk relative lebih lembab dan berbeda nyata dengan udara di luar tajuk. Juga dalam hal struktur stratifikasi komunitas hutan ini lebih kabur dan tampak tidak beraturan. Fisiognomi hutannya mencakup bentangan luas dengan tinggi rata-rata 25-30 meter untuk lapisan kanopi utama dan beberapa pohon mencuat yang tumbuh terpencar dengan tinggi mencapai lebih dari 35 meter. Pada lantai hutan yang lembab banyak ditemui berbagai jenis anakan pohon, palm hutan dan herba.

Berdasarkan pengamatan di lapangan, jenisjenis tumbuhan alami yang tercatat menghuni kanopi utama dan beberapa jenis pohon mencuat lainnya,diantaranya adalah Syzygium spp., Campnosperma sp., Litsea sp.,Intsia palembanica, Calophyllum inophyllum, Parinari corymbosa, Palaquium sp., Drypetes sp., Ficus spp., Knema spp., dan Calophyllum soulatri. Pada strata yang lebih rendah dapat dijumpai berbagai jenis individu pohon tingkat tiang yang kerapkali dililit oleh liana. Selain itu ditemukan pula berbagai jenis anakan maupun individu 
pohon tingkat pancang yang tersebar di lantai hutan yang relative lembab. Beberapajenis palm seperti rotan dan pinangyang umum terdapat di hutan dataran rendah juga dapat ditemui tumbuh terpancar.

Pada lokasi penelitian di tempat-tempat yang lebih terbuka atau pada gap-gap di tengah hutan, banyak ditemukanberbagai jenis tumbuhan sekunder yang menginvasi dan mengisi tempat kosong.Macaranga sp., Mallotus sp., Trema sp. dan Duabanga moluccana merupakan jenis perdu atau pohon sekunder yang kerapkali menginvasi. Sementara Sellaginella spp.,Alpinia sp. danAmpelocissus sp. umumnya merupakan jenis-jenis herba yang umumnya mengisi tempat-tempat kosong.

Berdasarkan hasil analisis data diketahui bahwa total kekayaan jenis tumbuhan yang tercatat dalam plotplot sampling pada lokasi penelitian ini terdiri atas 58 species, 48genus dan 35 famili tumbuhan tingkat tinggi. Famili Lauraceae mendominasi distribusi jenis pada areal penelitian ini $(10,16 \%)$ dan diikuti oleh Phyllantaceae dan Sapotaceae (keduanya 8,47 \%).

Pada kompleks hutan lindung ini, tampak terdapat perbedaan dalam hal komposisi jenis penyusun antara sub-komunitas hutan yang tumbuh di sebelah utara areal hutan lindung dengan jenis-jenis pohon dominan adalah Syzygium spp. dan Lithocarpus sp. serta sub-komunitas hutan yang terdapat di sebelah selatan areal hutan lindung yang tampak tidak terdapat jenis yang dominan dalam hal komposisi jenis sebagai mana diperlihatkan pada Tabel 1. Untuk perhitungan nilai kesamaan komunitas Motyka menunjukkan bahwa kedua sub-komunitas ini memiliki tingkat kesamaan dengan nilai23,54 \%. Nilai ini lebih kecil dari $50 \%$ yang berarti bahwa kedua sub-komunitas tersebut memiliki komposisi jenis yang cukup berbeda satu sama lainnya, atau dengan kata lain terdapat jenis dominan dalam hal luas bidang dasar suatu jenis tertentu pada salah satu sub-komunitas yang diperbandingkan.

Pada sub-komunitas I (SyzygiumLithocarpus)jenis Syzygium sp.1 merupakan jenis yang ditemukan tumbuh dominan, yang mana tercatat memiliki nilai penting yang tertinggi, yaitu sebesar $69,061 \%$ dan dengan presentase total luas bidang dasarnyauntuk sub-komunitas ini sebesar 51,685\%. Tingginya nilai penting dari pohon ini disebabkan karena jenis ini tumbuh melimpah dengan kerapatan individu yang tinggi, yaitu sekitar 208 individu untuk setiap hektarnya. Selanjutnya jenis Lithocarpus sp.1, juga ditemukan cukup melimpah pada areal ini, dengan nilai penting sebesar $32,183 \%$, kemudian diikuti dengan jenis Calophyllum inophyllum dan Litsea sp.1. Melimpahnya jenis-jenis ini diduga karena penyebaran propagule, buah atau biji jenis tersebut yang tidak jauh dari pohon induknya dan tampak tumbuh berdekatan satu sama lain atau dengan anakan yang tumbuh rapat di bawah pohon induknya.

Kenyataan pada areal sub komunitas I ini intensitas perburuan hewan-hewan yang berfungsi sebagai agen penyebar buah atau biji tumbuhan hutan relatif tinggi. Seperti kebiasaan masyarakat Suku Nua Agrovital | Jurnal Ilmu Pertanian Universitas Al Asyariah
Nea yang gemar berburu, baik untuk keperluan pemenuhan bahan makanan maupun untuk kelengkapan bahan upacara adat, maka beberapa jenis hewan yang sekiranya berperan sebagai agen dispersal aktif propagul pohon-pohon hutan, menjadi menurun populasinya akibat kegiatan perburuan yang sangat intens (Wattimena, 2014). Sebagaimana adat istiadat Suku Nua Nea tersebut pada waktu lampau, guna keperluan upacara inisiasi anggota masyarakat khususnya bagi kaum lelaki jika usianya telah beranjak dewasa, maka diwajibkan mempersembahkan kepala manusia yang ditaklukkan dalam perang untuk upacara inisiasi tersebut. Namun disaat sekarang ini kepala manusia telah digantikan dengan kepala hewan buruan, terutama kuskus (Phalanger orientalis) yang ditangkap di hutan. Terlebih lagi meningkatnya kesenangan berburu burungburung paruh bengkok yang juga diketahui sebagai salah satu hewan agen dispersal untuk pohon-pohon hutan di areal ini. Hal inilah yang diduga merupakan salah satu penyebab mengapa pohon-pohon hutan di areal ini cenderung tidak terdistribusi secara merata, akan tetapi propagulenya jatuh dan tumbuh berdekatan satu sama lainnya di sekitar pohon induk akibat menurunnya populasi hewan-hewan agen dispersal. Meskipun demikian, tentunya masih diperlukan penelitian khusus lebih lanjut untuk menjelaskan asumsi keterkaitan antara demografi pohon-pohon hutan di areal ini dengan keberadaan hewan-hewan yang berperan sebagai agen dispersal

Untuk komunitas II (Calophyllum-Syzygium), jenis yang memiliki nilai penting tertinggi adalah Syzygium sp.2, yaitu sebesar 23,760\%. Lalu kemudian jenis Calophyllum inophyllum dan Lithocarpus sp.1 dengan nilai penting berturut-turut sebesar 22,745\% dan 20,867\%. Akan tetapi, pada komunitas II (CalophyllumSyzygium) ini tampak tidak ada jenis tumbuhan yang terlalu mendominasi dalam hal jumlah jenis maupun jumlah individu dikarenakan penyebarannya tampak merata.

Untuk hasil perhitungan nilai keanekaragaman jenis memperlihatkan bahwa pada sub-komunitas Calophyllum-Syzygium, nilai keanekaragaman dan keanekaragaman maksimumnya lebih tinggi dibandingkan pada sub-komunitas SyzygiumLithocarpus. Hal ini tampaknya dipengaruhi oleh tingginya jumlah jenis yang tercatat pada sub komunitas Calophyllum-Syzygium ini. Tampak pula bahwa jumlah individu yang tercatat dapat mempengaruhi besarnya nilai keanekaragaman jenis pada suatu komunitas, yang mana diketahui bahwa rata-rata kerapatan jenis pada titik pengamatan II, yaitu sebesar 2883 individu/ha, lebih tinggi dibandingkan titik pengamatan I yang hanya sebesar 1683 individu/ha. Hal ini sejalan dengan Soegianto (1994) dan Sorianegara (1996) yang menyatakan bahwa keanekaragaman jenis organisme yang ada pada suatu komunitas tidak hanya ditentukan oleh banyaknya jenis yang menyusun, tetapi dapat pula dipengaruhi oleh jumlah individu dari setiap jenis yang ada pada komunitas tersebut. 


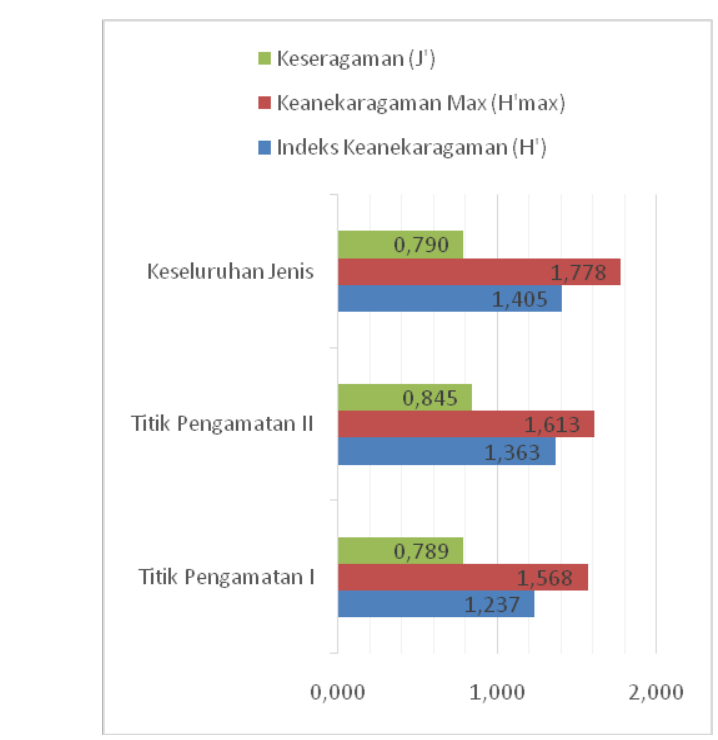

Gambar 2. Nilai Indeks Keanekaragaman jenis, Keanekaragaman maksimum dan keseragaman dari sub-komunitas I Syzygium-Lithocarpus, sub-komunitas II Calophyllum-Syzygium dan keseluruhan jenis yang ada di lokasi penelitian.

Demikian pula dengan nilai keseragaman, subKomunitas II Yang Lebih Tinggi, Memiliki Jenis-Jenis Penyusun Yang Lebih Menyebar Secara Merata Pada Plot-Plot Pengamatan Dan Relatif Tidak Memperlihatkan Adanya Dominasi Jenis Tertentu. Berbeda Dengan Sub Komunitas I, Yang Seperti Telah Dijelaskan Sebelumnya, Memiliki Jenis-Jenis Tertentu Yang Cenderung Mendominasi Plot Pengamatan. Meskipun Demikian, Secara Keseluruhan Vegetasi Hutan Ini Melingkupi Berbagai Jenis Tumbuhan Yang Terus Mengalami Dinamika Pertumbuhan Secara Alami. Selain Itu Berbagai Jenis Tumbuhan Dapat Menyebar Alami Dan Tumbuh Memperkaya Komunitas Di Setiap Mikro Habitat Pada Hutan Ini.

\section{Kesimpulan}

Dari Hasil Analisis Yang Dilakukan Dapat Disimpulkan Bahwa Total Kekayaan Jenis Tumbuhan Yang Tercatat Pada Plot Pengamtana Hutan Lindung Nua Nea Terdiri Atas 58 Species, 48 Genus Dan 35 Famili Tumbuhan. Famili Lauraceae Mendominasi Distribusi Jenis Pohon Pada Areal Penelitian Ini (10,16 \%) Dan Diikuti Oleh Phyllantaceae Dan Sapotaceae (Keduanya 8,47 \%). Pada Sub-Komunitas I SyzygiumLithocarpus Jenis Pohon Syzygium Sp.1 Merupakan Jenis Pohon Dominan Dengan Nilai Penting Yang Tertinggi, Yaitu Sebesar 69,061 \%. Untuk SubKomunitas II Calophyllum-Syzygium, Jenis Pohon Yang Memiliki Nilai Penting Tertinggi Adalah Syzygium Sp.2, Yaitu Sebesar 23,76 \%. Namun Demikian, Pada Komunitas II Ini Tampak Tidak Ada Jenis Yang Terlalu Mendominasi Dalam Hal Jumlah Jenis Maupun Jumlah Agrovital | Jurnal Ilmu Pertanian Universitas Al Asyariah
Individu. Demikian Pula Dengan Hasil Perhitungan Keanekaragaman Jenis Memperlihatkan Bahwa Pada Titik Pengamatan II Di Sebelah Selatan Areal Penelitian, Nilai Keanekaragaman Dan Keanekaragaman Maksimumnya Yang Lebih Tinggi Dibandingkan Pada Titik Pengamatan I Di Sebelah Utara Areal Penelitian.

Dengan Beragamnya Jenis Pohon Yang Dijumpai Pada Areal Ini Secara Langsung Dapat Berperan Sebagai Salahsatu Kawasan Penyangga Bagi Taman Nasional Manusela Yang Bersebelahan, Yang Mana Dapat Dimanfaatkan Oleh Satwa Liar Menjadi Koridor Areal Pengungsian Untuk Mencari Makan Dan Berbiak Pada Saat Musim Paceklik Pakan Di Zona Inti Taman Nasional. Oleh Karena Itu Perlu Perhatian Lebih Dalam Menjamin Keberlangsungan Keberadaan Hutan Lindung Ini Dalam Kaitannya Dengan Terjaganya Ekosistem Hutan Di Taman Nasional Manusela. Aturan Perburuan Satwa Liar Perlu Pula Diperketat Dalam Upaya Menjaga Keberlangsungan Hidup Jenis-Jenis Satwa Liar Itu Sendiri Di Alam Dan Keberlangsungan Ekologi Hutan Lindung Secara Keseluruhan.

Selain Itu Dengan Terjaganya Fungsi Hutan Lindung Ini, Yaitu Sebagai Pengatur Tata Air, Maka Proses-Proses Hidrologi Yang Ada Pada Hamparan Hutan Ini Dapat Berlangsung Secara Optimal Dan Dapat Memberikan Manfaat Lebih, Menjamin Tersedianya Debit Air Yang Mencukupi Sepanjang Tahun.

\section{Daftar Pustaka}

Brower, J. E., J. H. Zar and C. N. Von Ende. 1990. Field and laboratory methods for general ecology (3th. Ed.). Wm. C. Brown Publisher. Doduque, Iowa.

Cosiaux A. 2014. Local uses of tree species and contribution of mixed tree gardens to livelihoods in Saleman: Village near Manusela National Park, Seram Island, Maluku (Indonesia). Working Paper 137 CIFOR. Bogor, Indonesia.

Magurran, A.E. 1987. Ecological Diversity and Its Measurement. London: Chapman and Hill : $\mathrm{X}+179 \mathrm{hlm}$.

Mueller-Dombois, D. and Ellenberg, H. 1974. Aims and Methods of Vegetation Ecology. Canada: John Wiley and Sons, Inc : XX + $547 \mathrm{hlm}$.

Soegianto, A. 1994. Ekologi Kuantitatif: Metode Analisis Populasi dan Komunitas. Jakarta: Penerbit Usaha Nasional.

Soerianegara, I. 1996. Ekologisme Dalam KonsepPengelolaan Sumberdaya Hutan Secara Lestari dalam Ekologi, Ekologisme dan PengelolaanSumberdaya Hutan. E. Suhendang; C. Kusmana; Istomo \& L. Syaufina (Editor).Jurusan Manajemen Hutan IPB. Bogor.

Soerianegara, I dan Indrawan, A. 2002. Ekologi Hutan Indonesia. Bogor: Laboratorium Ekologi 
Hutan. Fakultas Kehutanan Institut Pertanian Bogor.

Souhuwat, W. 2006. Studi Pemanfaatan Hasil Hutan Oleh Masyarakat Sekitar Taman Nasional Manusela, Studi Kasus Desa Horale, Desa Masihulan, Desa Air Besar, Desa Solea dan Desa Pasahari. (Skripsi) Departemen
Konservasi Sumberdaya Hutan dan Ekowisata, Fakultas Kehutanan, Institut Pertanian Bogor.

Wattimena, L. 2014. Rumah Adat di Pesisir Selatan Pulau Seram, Maluku Tinjauan Awal Etnoarkeologi. Jurnal Humaniora Volume 26: $226-275$. 